\title{
HOW CLASSROOM TALK CONTRIBUTES TO READING COMPREHENSION
}

Nastassja Maree

Rooihuiskraal Primary School

Gert van der Westhuizen

University of Johannesburg

\begin{abstract}
This article is an inquiry into how classroom talk among learners and a teacher in a reading class contributes to comprehension. It draws on sociocultural perspectives on school learning (Melander, 2012; Pellegrino, 2020; Stahl, 2002), conversation analysis research of human interaction in the humanities (Edwards 1997, 2001; Tanner 2017) and teachers' open invitations in whole-class discussion within classrooms (Koole \& Elbers, 2014; Seedhouse, 2004). Video recordings of learner interactions have been transcribed by means of the Jefferson (1984) conventions and analysed by means of the conversation analysis framework of Clayman and Gill (2004). This framework draws on conversation analysis principles developed in various disciplines, and allows for a detailed analysis of what the comprehension interactions were about and how they were conducted for the purpose of comprehension. Analyses were considered based on sequence organisation, response preferences, lexical choices and gestures.
\end{abstract}

Findings indicate that grade 4 learners use talk in creative, spontaneous and dedicated ways in their attempts to understand a text during a classroom lesson. Learners take turns at talking in ways that reflect their personal understandings of words and sentences, and interact in ways which clarify their own understanding of meanings. Non-verbal behaviour such as pointing, excitement, interruptions, tone of voice, faster and slower speech, sighs and observations are all patterns observed which, in the context of conversation sequences, contributed to interpretations of difficult words and also offered answers to comprehension questions. Findings are discussed in terms of the social actions associated with classroom talk, the value of independent attempts of meaning making and talking about the text for shared comprehension.

Keywords: reading comprehension interaction, classroom talk, conversation analysis, peer learning, comprehension teaching

\section{INTRODUCTION}

Reading comprehension is the cornerstone of literacy development in schools (Alvemann \& Earle, 2013; Beaty, 2015; Byrd, 2017). Challenges of poor comprehension levels in school literacy programmes have been observed as early as grade 4, where it is estimated that up to $60 \%$ of children read with poor comprehension (Van der Berg, 2016). In South Africa, this 
seems to be a general trend, judging from findings from PIRLS studies (PIRLS, 2018; Van Staden, 2011) which have indicated overall scholastic underachievement and children falling behind on the content of the curriculum in other school subjects (Cain \& Oakhill, 2006; Ricketts, Sperring \& Nation, 2014).

The problem of poor reading performance in South African schools is also evident in the results of the Annual National Assessments. These assessments have indicated that the literacy skills of learners are far below the expected norm (South Africa, Department of Basic Education, 2014). This has a ripple effect, with poor reading abilities affecting comprehension and poor school performance in subject areas such as mathematics (Cimmiyotti, 2013; Grimm, 2008).

Interactions in the classroom have been found to be an integral part of the development of reading comprehension (Palinscar \& Brown, 1984; Slavin, 2015; Wolf, Crosson \& Resnick, 2005). They involve conversations which foster an active learning experience where children are 'granted' access to their own learning and build on each other's ideas and formulations. These contributions from both teacher and learners lead to new understandings, deeper insight and the production of new knowledge (Kiemer, Gröschner, Pehmer \& Seidel, 2015; Michaels \& O'Conner, 2012; Renninger \& Hidi, 2011; Walshaw \& Anthony, 2008).

Responses to the need for improving reading comprehension have taken different forms over the last few years, such as the inclusion of the teaching of comprehension strategies and the extended use of opportunities to 'practise' comprehension by reading and answering comprehension questions (Curriculum and Assessment Policy Statement [CAPS], 2010). The need for research into the ways in which reading comprehension can best be taught, is ongoing. The tradition of studies into comprehension strategy development advocated by Pressley, El-Dinary, Gaskins, Schuder, Bergman, Almasi and Brown (1992), Paris, Cross and Lipson (1984) and Paris and Winograd (1990) seems to have shifted to a focus on classroom interactions and peer learning. This shift is confirmed by the reviews of Wolf et al. (2005) and Beck (2001) which highlight the possibilities of what readers learn in classroom interactions and from one another when they talk about a text, and specifically how they use talk for answering comprehension questions.

The purpose of this study was to analyse examples of classroom interactions in order to understand how conversations and talk contribute to comprehension of texts in reading lessons.

\section{INTERACTION IN READING CLASSROOMS}

Classroom lessons aimed at improving reading can be looked at as social processes where participants explore a shared need to read and understand a text together. In such classrooms, learning and cognitive development are, in Vygotskian (1986: 287) terms, 'embedded within social events and occurring as a child interacts with people, objects and events in the environment'. Such interaction is key to learning in that inter-mental activity, that is, learners interacting with mediating others, is transferred to intra-mental activity, that is, internalised cognitive development (Kozulin, 2003). Kucan and Beck (1997) have long argued that learners need to talk about their learning experiences in order for the learning to be internalised and become an integral part of themselves. By means of dialogue, interactional learning and reading development is enabled (Mercer \& Littleton, 2007; Simpson, Mercer \& Majors, 2010). Productive interaction and collaborative learning are the result of students 
explaining ideas, expressing contrasting opinions and reasoning in groups as interactive processes in situations of learning difficult content (Mercer, 2012), gains which are also evident in reading comprehension interactions.

Reading is a constructive and interactive transaction between the individual and the text, peers, the teacher and the context (Van Staden \& Bosker, 2014: 1). The transactional dimension of reading interactions is part of what Seedhouse (2004: 234) calls the interactional architecture of language classrooms, which involves reflexive relationships and the conversational actions taken by participants, such as clarification requests, confirmation checks, comprehension checks and self-repetitions. Learner talk in classrooms has to do with conversations and interactions between learners, which guide the thinking, understanding and knowing that is produced and acquired as learners derive meaning from content by means of talk as discursive activity (Seedhouse, 2004: 242-243). Learning and understanding are being constructed together as an interactional accomplishment (Melander, 2012: 233) and the social construction of meaning (Brown, 1994: 7).

Interactions in language classrooms are conversational in nature, typically involving competent novice learners in conversation with experienced speakers who invite conversational responses (Johnson, 1995: 75; Seedhouse, 2004: 6). This perspective implies a reflexive relation between pedagogy and interaction - with changes in pedagogy come changes in the organisation of interaction, and changes in the intended curriculum to the actual manifested curriculum (Seedhouse, 2004: 11).

The value of classroom interaction for the development of reading comprehension has been demonstrated by the studies by Palinscar and Brown (1984). Reciprocal teaching methods assume teaching to be dialogic in nature, where dialogues between teachers and learners define meanings of a text together (Palinscar \& Brown, 1984; 121-122; Rosenshine \& Meister, 1994: 480). Reciprocal teaching facilitates comprehension by ensuring that learners play an active role conversing in small groups about their reading and, in the process, improving comprehension and collaboration between learners and teachers (Oczkus, 2003; Palincsar, 1986). During discussions, learners are able to think and elaborate on ideas and notions about the text, while receiving valuable input from others. Discussion can be expanded and elaborated to guide thinking and knowing until consensus is reached between and within each participant, thus leading to the necessary comprehension (see Seedhouse, 2004: 9; Wolf et al., 2005: 28).

Reading comprehension interactions can be regarded as opportunities to think together, and enhance reasoning, problem-solving and learning (Mercer, Dawes \& Staarman, 2009: 357). Cooperative learning holds major benefits for learners (Gillies, 2016: 51). It provides learners with opportunities to elaborate their answers, while at the same time checking their own and others' understanding, and sharing the responsibility to comprehend the text. Such interactions encourage learners to think about the text in new ways and consider alternative perspectives (Hurts et al., 2013: 376). This inquiry is an exploration of classroom interactions, of what is involved in interactions among learners, and between the teacher and learners, aimed at the comprehension of a text. We explore such comprehension conversations, what they cover in terms of content and how they are conducted. 


\section{METHOD OF INQUIRY}

The study is an ethnomethodological study of interactions in a natural setting, in the research design tradition of Garfinkel (1976), Sacks (1992) and others (see Ro, 2019). This tradition focuses on the methods people use to understand their social worlds, which in the case of a reading lesson involves interaction and turn taking in a reading comprehension lesson.

The sampling was purposeful and convenient, and consisted of one group of six grade 4 learners in a class of 36. All the learners in the class participated in the reading lesson. The interaction of one group was transcribed for detailed analysis. This group was randomly selected and varied in terms of gender, socioeconomic backgrounds and abilities. The study was conducted with the required ethics approval of the institution, and the consent and assent of participants.

Data were gathered during a reading comprehension lesson at a primary school in an urban area in Gauteng. The lesson was part of the normal curriculum and was observed during the Afrikaans First Language period. The lesson of 20 minutes was presented by the subject teacher and consisted of a reading activity prepared by the teacher according to the CAPS curriculum. The lesson consisted of a grade 4-level reading comprehension text with questions that had to be answered. The learners had to discuss the text and comprehension questions in groups consisting of six learners per group. The text was entitled 'Blinkblaar wag-'n-bietjie kompetisie' (Buffalo thorn tree competition), and the comprehension questions included both questions of content and of context.

The lesson was video-recorded and transcribed with the Jefferson (1984) notations, which is the norm for conversation analysis research (Ten Have, 2007). The analysis was done in terms of the four levels of conversation analysis developed by Clayman and Gill (2004). This framework has been found to be useful for answering research questions on what conversations are about and how they are conducted (Du Preez, 2015; Pretorius, 2015). With regard to the question of the content of the reading comprehension class conversation, the analysis would describe topics and nested layers of interaction. On the question of how the conversations were conducted, the analysis would reveal the use of discrete sequences of action, such as question-answer, statement-response and noticeable sections of talk. In addition, this analysis would clarify singular utterances and response preferences and how they relate and contribute to comprehension. Lastly, the analysis accounted for nonverbal actions and other turn components regarding their contribution to comprehension.

\section{FINDINGS}

The inquiry considered how talk was used for comprehension in the reading classroom by means of analysing what learners talked about and how they interacted. For this analysis, two illustrative episodes have been selected: one on understanding a difficult word and one on the answering of a specific comprehension question.

\section{Comprehension interactions around a difficult word}

The segment in Table 1 is the interaction from lines 67 to 111 around the question about the meaning of the word weerhake, which was question six of the comprehension exercise. 
Table 1: Segment of interaction around the meaning of the word 'weerhake'

\begin{tabular}{|c|c|c|}
\hline $\begin{array}{l}69 \\
70\end{array}$ & L5: & $\begin{array}{l}\text { ((reads question 6)) wat is die geniepsige weerhake in } \\
\text { paragraaf } \\
\text { what is the malicious barbs in paragraph } \\
4 \text { eintlik? } \\
4 \text { actually? } \\
\text { ((he then silently reads paragraph } 4)) \\
\text { ((confused not knowing what is going on)) }\end{array}$ \\
\hline $\begin{array}{l}71 \\
72\end{array}$ & & $\begin{array}{l}\text { ((all the learners are staring at each-other })) \\
((\text { pause }))\end{array}$ \\
\hline 73 & Teacher: & $\begin{array}{l}\text { ok } \uparrow \text { kom ons lees nou weer die vraag } \\
\text { let us read the question again } \\
\text { die vra:ag is.. } \\
\text { ((turning the page)) } \\
\text { wat: is die geniepsige <weerhake> in paragraaf 4. eintlik? } \\
\text { what is the malicious barbs in paragraph } 4 \text { actually? } \\
\text { wat dink: julle is dit= } \\
\text { what do you think it is }\end{array}$ \\
\hline 78 & L1: & $\begin{array}{l}=\uparrow \text { juffrou } \downarrow \text { ek dink dis 'n ha:ar-rige stam } \\
\text { teacher I think it is a hairy trunk } \\
\text { ((waves hand in circle) })\end{array}$ \\
\hline 79 & Teacher: & $\begin{array}{l}\text { >hoekom sê jy so<? } \\
\text { why do you say that }\end{array}$ \\
\hline 80 & L1: & $\begin{array}{l}\text { ( ) want hy sê dis geniepsig } \\
\text { because he says it is malicious } \\
\text { ((nodding head)) }\end{array}$ \\
\hline 82 & Teacher: & $\begin{array}{l}\text { ok: dis geniepsig. }>\text { maar wat is ' } \mathrm{n} \text { weerhaak }< \\
\text { ok it is malicious, but what is a barb } \\
\text { kom }>\text { ons dink ' } \mathrm{n} \text { bietjie }<\uparrow \text { wat is ' } \mathrm{n}<\underline{\text { weerhaak }>} \\
\text { let us think for a moment what a barb can be }\end{array}$ \\
\hline $\begin{array}{l}84 \\
85 \\
86 \\
87\end{array}$ & & $\begin{array}{l}\text { ((children looking at each other })) \\
((\text { frowns })) \\
((\text { pens clicking })) \\
((\text { pause }))\end{array}$ \\
\hline $\begin{array}{l}89 \\
90\end{array}$ & Teacher: & $\begin{array}{l}\text { as ons die sinnetjie we:er lees } \uparrow \mathrm{kyk} \downarrow \text { hierso } \\
\text { if we read the question again, look here } \\
\text { ((turns page)) } \\
>\text { dan sal ons }<<\text { sie:: } \mathrm{n}> \\
\text { then we will see } \\
\text { praat hulle daar van.. } \uparrow<\text { dan help hulle om jou te } \\
\text { beskerm }>\uparrow \\
\text { they are talking about helping to protect you } \\
>\text { teen die }<\uparrow \text { wee:rha:ak? } \\
\text { against the barbs } \\
\text { ((pause)) } \\
\text { wat dink jy kan ' } \mathrm{n} \uparrow \text { weerhaak } \uparrow \text { wees } \\
\text { what do you think a barb can be }\end{array}$ \\
\hline
\end{tabular}

\footnotetext{
${ }^{1}$ The phrases in italics are direct translations.

Per Linguam 2020 36(2):1-15

http://dx.doi.org/10.5785/36-2-910
} 


\begin{tabular}{|c|c|c|}
\hline 95 & L1 and L4 & ((silence, then two children raising hands)) \\
\hline 96 & L4: & ((quickly lowering hand and touching head)) \\
\hline 97 & & $((\operatorname{ahhh} \uparrow))$ \\
\hline 98 & & $((\mathrm{mmm} \ldots))$ \\
\hline 99 & & $\uparrow o p$ 'n boom $\uparrow$ \\
\hline 101 & & $\begin{array}{l}\text { on a tree } \\
((\text { pause }))\end{array}$ \\
\hline 102 & Teacher: & 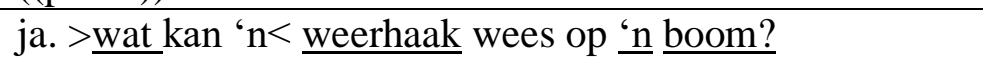 \\
\hline & & yes what can a barb be on a tree \\
\hline 103 & & dink 'n bietjie.... \\
\hline & & think for a bit \\
\hline 104 & & $\begin{array}{l}\text { onthou: hy klim nou teen die boom op:: en nou } \\
\text { remember he is climbing up against the tree and now }\end{array}$ \\
\hline 105 & & $\underset{\text { is }<}{\uparrow \text { beskerm } \uparrow}$ sy skoene hom: > teen iets wat teen die boom \\
\hline 106 & & $\begin{array}{l}\text { his shoes are protecting him against something against } \\
\text { the tree } \\
((\text { silence }))\end{array}$ \\
\hline 107 & L1: & $\begin{array}{l}\text { [[DORINGS!]] } \\
\text { THORNS! }\end{array}$ \\
\hline 108 & L4: & $\begin{array}{l}{[[j u f f r o u} \\
\text { teacher, thorns }\end{array}$ \\
\hline 109 & L1: & $\begin{array}{l}>>=\text { wat so kan deursteek.. }<<\text { juffrou: }>>\text { wat hom die } \\
\text { heeltyd }\end{array}$ \\
\hline 110 & & $\begin{array}{l}\text { they can stick through, teacher, that wants to } \\
\text { wil keer juffrou<< } \\
\text { halter him the whole time, teacher }\end{array}$ \\
\hline 111 & & $(($ writing $))$ \\
\hline
\end{tabular}

The key for the transcription notations is in Addendum A.

In this episode, L5 asks a question about the meaning of the word 'weerhake' (barbs). The teacher responds by suggesting that they read the comprehension question about this word, and in so doing, invites answers. L1 responds with a suggestion which the teacher uses to probe the questions, asking L1 to account for her suggestion in line 79. In line 82, the teacher accepts the account and asks a follow-up question. This encourages the class to think more, which is the space used by the teacher to repeat the original comprehension question in line 88 and offer an interpretation for the class to consider. This invitation is considered in line 102, in the extended question: what can a 'weerhaak' (barb) be in a tree? This leads to L1 and L4 to respond and confirm their understanding.

From the transcription, the how of the interaction can be observed. It is evident that the sequences consist mostly of the question-answer and invitation-response kind. The pace of actions clearly serves the purposes of inviting learners to share their understanding of meanings and clarifying meanings as a group. In line 73 , the teacher observes the learners struggling (through silences and mannerisms in lines 69-72), then uses an invitation utterance to invite them back to respond to the question about the meaning of the word 'weerhake' (barbs). This is done in order to facilitate some responses and ideas that the learners may have, and the invitation succeeds, as seen in L1's response in line 77 and 80 . This sequence 
serves to keep the conversation on track (as seen in lines 75, 79 and 83) and to guide the learners towards the understanding of the word meaning. In line 83, the teacher poses a question as a repair (other repair) of prior talk by saying 'kom $>$ ons dink ' $\mathrm{n}$ bietjie $<\uparrow$ wat is ' $\mathrm{n}<$ weerhaak $>$ ' (let us think for a bit, what is a barb?). In lines 92 and 94, the teacher uses the same question again to probe responses from the learners. This results in two learners attempting to answer in line 95 and the utterance that follows in line 99, and gives rise to the desired direction of the conversation (as attempted by the teacher as facilitator). A paired action can be observed in line 102 and again in line 105, where the teacher uses the utterance of L4 in line 99, 'op ' $n$ boom', to keep the flow and direction of conversation. The learners then come to understanding and establish what the meaning of weerhake (barbs) is that the question asks (lines 107 and 108). L1 then goes further by explaining what this means according to L4's utterance (lines 109 and 110).

In the episode, talk is used to add to the understanding of the difficult word. As seen in lines 91 and 105, the teacher uses the statement/announcement of 'shoes that are protecting the child's feet against something' as a thinking tool accomplishing action and response (lines 107-110). The utterance ' $n$ boom' (a tree) by L4 is used a few times by the teacher to direct attention and as a thinking device to guide thoughts on the specific question/subject (lines 102 and 105). Ultimately, the teacher uses the statement in line 105 'something that is against the tree' as an invitation to direct the learners' response and understanding. The statementresponse sequence in line 109 serves to confirm L1's excitement about the answer she responded with in line 107.

In analysing the how of the conversation, further to the above analysis of sequence types, specific response preferences and non-vocal behaviours can be observed. In lines 69 to 72, for example, uncertainty is observed when the learners do not know what the answer is. In line $78, \mathrm{~L} 1$ waves her hands in a circle to try to demonstrate what she means. In lines 84 to 87, the learners all use non-verbal behaviour, suggesting insecurity and uncertainty after the question probed by the teacher in the previous line. This leads the conversation in a different direction where the teacher then expands and extends on phrases and previous utterances to try and simplify the word or question for the learners. Directly after this, two learners raise their hands (line 95) and seem to know the answer. In lines 96 to 101, L4 is given the opportunity to answer, but then seems unsure of himself, as shown in the utterances 'ahh' and 'mmm' in lines 97 and 98 and only giving some clues as to what he is thinking (line 99). This can be taken as a token that he is gathering his thoughts and reflecting on his thinking. There is then a pause (line 101), which leads to action taken by the teacher to guide his utterance from line 99. In line 106, the silence can be perceived as a thinking moment, as emphasised in the shouting of the answer in line 107 and the discussions that follow onwards. In line 101, there is a pause which allows the learner to reflect on his thoughts and re-consider what he wants or means to say. Intonation contours are used widely in this extract, as seen in, for example, line 73. In line 75, the word 'weerhake' (barbs) is emphasised by slower pronunciation by the teacher, as well as the words 'in' and 'eintlik' (actually). Lines 76 to 77 can be regarded as the excitement that comes about from L1, where the learner self-selects her turn and provides a possible answer, and her initial tone of voice rises. In line 82, the teacher speeds up the sentence to divert the attention away from the learner's answer as it was actually incorrect, thus guiding the conversation towards 'weerhake' again: '>maar wat is ' $\mathrm{n}$ weerhaak<' (but what is a barb). The words 'ons' (we) and '<sie::n $>$ ' (see) are stressed in lines 88 and 90, to motivate the learners to read along in their texts. Every time the word 'weerhake' (barbs) is used, it is emphasised one way or another, for example, by being louder, slower or stressed. Lines 107 and 109 are directly linked through intonations, where Per Linguam 2020 36(2):1-15 http://dx.doi.org/10.5785/36-2-910 
L1 and L4 shout out the answer simultaneously; then, L1 self-selects again by the very fast speech as seen in line 109. This also emphasises her comprehension and understanding of the word within its context (thus showing some of the learning that happened in this interaction). In line 111, the learners all come to understanding as they write down their answers.

In summary, the content of the interaction around the meaning of the word 'weerhake' (barbs) covered questions about meanings, extended questions, bridging questions and probing questions. As far as the how of the conversation is concerned, following Clayman and Gill's (2004) levels of analysis, specific sequences, response preferences and gestures contributed in very specific ways to the accomplishment of understanding of the word. The sequence types included question-answer, question-answer-feedback and statement-response, and they served purposes of focusing, keeping momentum and probing the understanding of word meaning. The conversation was characterised by gestures, loudness of voice, fast talking and pausing - all tokens of the serious attempts on the part of learners to comprehend the word.

\section{How group talk is used to answer a text comprehension question}

In the second analysis, the focus was on a segment which illustrates how group talk adds to comprehension. The interaction was around one of the text comprehension questions: 'Why would rain boots protect your feet against a thorn tree?' The analysis again involved what the talking was about and how it was conducted.

Table 2: Interaction around a specific comprehension question

\begin{tabular}{|c|c|c|}
\hline 112 & L3: & $\begin{array}{l}\text { ((reads question } 7)) \text { hoekom kan reënstewels goeie beskerming } \\
\text { why can rainboots be good protection } \\
\text { daarteen bied? } \\
\text { against it? }\end{array}$ \\
\hline 114 & L4: & $\begin{array}{l}{[[\text { want sy }]]} \\
\text { because his }\end{array}$ \\
\hline $\begin{array}{l}116 \\
117\end{array}$ & L1: & $\begin{array}{l}\text { [[want daai:::]] goed } \\
\text { because that stuff } \\
\text { ((can’t find word) })((\text { tries explaining with hand gestures })) \\
\text { [is dik }]= \\
\text { are thick }\end{array}$ \\
\hline 118 & L4: & $\begin{array}{c}=\text { sy [rubber:] goed is dik? } \\
\text { his rubber stuff is thick? }\end{array}$ \\
\hline 120 & L3: & $\begin{array}{l}\text { wat- } \\
\text { what } \\
((\text { interrupted by L6)) }\end{array}$ \\
\hline 121 & L6: & $\begin{array}{l}{[[()]]} \\
()\end{array}$ \\
\hline 122 & L3: & $\begin{array}{l}{[[\text { wat }]] \ldots . . . \text { wat }} \\
\text { what what }\end{array}$ \\
\hline 123 & L3: & $\begin{array}{l}>\text { [die skoene se rubber is dik] }<? \\
\text { the shoes' rubber is thick }\end{array}$ \\
\hline 124 & L4: & $\begin{array}{l}\text { [die skoene se rubbers is dik] } \\
\text { the shoes' rubber is thick }\end{array}$ \\
\hline 125 & L2: & $\begin{array}{l}\text { en dan help dit om jou voete te beskerm () dorings! } \\
\text { and then it helps to protect your feet from the thorns }\end{array}$ \\
\hline
\end{tabular}

This segment starts with the teacher referring to the comprehension test question in line 112 . This is followed in line 125 with L2 making an announcement providing the reason why and Per Linguam 2020 36(2):1-15 
how the shoes are good protection, thus giving clarity as to the previous utterances made about the thick soles of the shoes and the relevance thereof. In line 118, L4 poses a question, thus inviting a response from L1 as to what she means with her statement made in the previous turn. This also provides clarity on the preceding turns. L3 asks a question in line 123 which actions L4 to confirm her understanding: ' $>$ [die skoene se rubber is dik] $<$ ?' (the shoes' rubber is thick). L4 takes this account further by adding and confirming to the utterance 'want die skoene se rubbers is dik' (because the shoes' rubber is thick), concluding the exchange and ensuring a complete answer for the group (line 124).

Group interaction in this segment includes paired actions, with turns used to follow up, interrupt and confirm previous turns. L4 and L1 attempt to answer the comprehension question by uttering the statements 'want sy' (because his) and 'want daai goed' (because that stuff) (lines 114 and 115) simultaneously as they are sharing similar ideas, considered paired actions, but cannot seem to find the correct words to express their meanings. The utterance in line 115 is a repair action changing the words of the previous turn. In line 118, L4 completes L1's sentence with the desired word, posing a question whether he is making the correct assumption, thus inviting response. L3, in line 119, presumably wants to ask a question, but is then interrupted by L6. The overlap talk and actions of interruption seem to do the work of information sharing and extending of interpretations of previous turns. The question-answer sequence in lines 122 to 124 follows in a paired action of confirmation from L4. L2 then makes a statement that pairs this answer with the conversation in learning episode 1 in Table 1, where she emphasises the relevance of the shoes within the context of the thorns. Learner talk in this segment does the work of collaborative learning where learners assist each other in clarification and understanding.

The response preference by L1 in 115, 'daai:: goed' (that stuff), does the work of prompting and inviting the group to help find the correct words. Group members respond and use their turns in line 118 onwards to support the meaning-making effort. In line 116, a learner uses hand gestures to explain to the group what he means. This learner's confusion about the correct word is also seen in this turn through his body language. The overlaps and interruptions between L3 and L6 are tokens of individual attempts to contribute to the understanding, resulting in line 123 where L3 self-selects through fast speech patterns to utter her idea about what she thinks this answer may lead to. In line 125, L2 makes an addition to the previous utterance by emphasising '...en dan...' (and then) and self-selects a turn by this speech strategy, adding that the shoes will protect against the thorns as determined in the previous question.

The group interaction in this episode is a display of a collective and combined effort of using turns, gestures, interruptions and response preferences to arrive at an account of the meaning together. The turns by L1, L2, L3 and L4 combined in one statement of what the meaning and answer to the comprehension question are.

In summary: the analyses of this and the previous episodes indicate that the content or what of the conversation was related to the interaction purpose, with participants using their turns to share their individual understanding, responding to other turns and working towards a shared or group understanding. As far as the how of the interactions are concerned, we identified specific sequence types. These were mostly question-answer and statementresponse sequences which included corrections and self-repair, paired actions and response preferences aimed at clarifying word meanings. The non-vocal actions, such as silences, 
raising hands, interruptions and overlap talk seemed to mostly do the work of indicating uncertainty, changing direction of the interaction and contributing to meaning making.

\section{DISCUSSION}

The analysis of the two segments of interaction indicate how comprehension conversations are guided by the purpose of clarifying meanings and achieving comprehension. The focus on learner talk revealed how participation is aligned with the purpose of the conversation. We also show how talk is used to communicate individual understanding, and how such sharing is used by others to extend their own comprehension and work towards a shared and agreed upon understanding.

Reading comprehension is a collaborative process, as the learners and the teacher coconstruct the meaning of the text, which is essential for understanding, drawing on individual and shared understandings. The episode on the word meaning is an example of a shared conversational effort and is evidence of what Koschmann (2013: 1038) calls 'learning-inand-as-interaction'. Learning and knowledge are both the object of the interaction and the basis for the flow of the interaction (Van der Westhuizen, 2015).

Talk was used in both interactions to achieve outcomes - conversational utterances and other practices of interruption were used to express thinking and share ideas and views to steer interactional learning. This interaction clearly demonstrated that understanding, in Mondada's (2011: 543) terms, could 'not be treated as a mental process but is related to the next action achieved by the co-participant'.

The findings indicate that reading comprehension is a collaborative process, as the learners and the teacher co-construct meanings of the text, which is essential for understanding. Learners need to elaborate their ideas in order to reflect on their thinking, and this is established through the methods they use, seen in conversation.

Comprehension of text needs to be seen as an active accomplishment where the learners accomplish and come to insight together through the use of talk which enables true reflective learning. As seen in the above analyses, learners used each other's ideas, knowledge bases, reasoning skills and reading comprehension strategies to guide overall thinking and learning around the text. In most of the sequences and episodes, the learners all collaborated in finding the answers about the text. When talking, learners take responsibility for the ideas that they share, and they learn to reason and critically analyse their own and others' ideas about text, as participants use talk to respond to one another and to move the interaction in appropriate directions given the setting and educational purpose (Van der Westhuizen, Pretorius \& Tillema 2020). Learners will then also come to realise that knowing and understanding is a process that we arrive at through meaningful interactions, together. One learner would use a preceding notion, thought, utterance or talk sequence and use that to build his or her own knowledge structure. Then, the next learners would take these following thoughts and yet again do the same, until they come to a conclusion.

The finding that incomplete utterances occurred in the interactions is significant. The interaction can be seen as peer learning which, in Boud's (2001) terms, enabled and expanded the learners' learning. This ensured that there was some initial response that grounded ideas and facilitated further thinking, which could be explained in context of the answer, but this only happened because of interactional attempts of shared knowledge during conversation. 
As social learning theories are highly valued, and even more so for the purpose of this study, the practice of teachers doing all of the talking in classrooms is problematic and in direct contrast to the view that learning is a social activity (Dewey, 1963). This implies that the person who is doing the work is the person doing the learning (Hurts, Wallace \& Nixon, 1998: 376). 'Too much of learning consists of vicarious substitution of someone else's experience and knowledge' (Lindeman, 1926: 6). For this reason, it is important that teachers make classrooms social, interactional and lively, with conversation between and among teachers and learners. As seen in this study, this is facilitated when the teacher makes use of learners' questions and utterances to prompt and guide further extended talk which 'make[s] thinking public', a valuable comprehension teaching strategy. The value of such probing, as noted by Wolf et al. (2005: 46), is associated with learners' answers being more complete and learner understanding of text being improved. Closed questions, yes/no questions and questions eliciting short answers seem to add less to the substantive understanding of a text. Pressing strategies, on the other hand, where the teacher keeps on probing and encouraging learners to expand on their answers, add to more rigorous discussions and substantive understanding of a text (Nystrand, Gamoran, Zeiser \& Long, 2003; Wolf et al., 2005).

\section{CONCLUSION}

This study is a limited exploration of what is involved in text comprehension conversations and how they are conducted in a classroom setting. The study is exemplary of conversation analysis research, which is gaining ground in studies of literacy learning. The particular contribution is in the descriptions of the ways in which talk was used by participants for the interactional accomplishment of comprehension. While the findings are by no means conclusive, they highlight how comprehension is pursued and achieved by means of specific forms of sequencings, turn constructions and response preferences.

The study deepens the understanding of the conversational dimensions of educational interactions in reading classrooms. Pedagogical implications of interaction sequences and how they relate to reading comprehension outcomes may be further explored. The implications are that teachers may develop their comprehension teaching by means of a conversation pedagogy, similar to what has been advocated by Magano, Mostert and van der Westhuizen (2010). The emphasis on classroom talk, from an educational perspective, is an invitation to learners to consider and share their own understanding, and in so doing, contribute to the co-construction of knowledge and learning outcomes.

\section{REFERENCES}

ADLER, CR. 2001. Put reading first: The research blocks for teaching children to read. Jessup, MD: ED Pubs.

ALVERMANN, D \& J EARLE. 2003. Comprehension instruction. In Sweet, AP \& C Snow (Eds.), Rethinking reading comprehension. New York: Guilford Press. 12-30.

BOUD, D. 2001. Introduction: Making the move to peer learning. In Boud, D, R Cohen \& J Sampson, (Eds.), Peer learning in higher education: Learning from and with each other, London: Kogan Page. 1-17.

BECK, EL. 2001. Text-talk: Capturing the Benefits of Read-aloud Experiences for Young Children. International Reading Association, the Reading Teacher, 55(1):10-20.

BROWN AL. 1994. The advancement of learning. Educational Researcher, 4-12.

BYRD, JL. 2017. Best practices for increasing reading self-efficacy (Doctoral dissertation, CarsonNewman University). 
CAIN, K \& J OAKHILL. 2006. Profiles of children with specific reading comprehension difficulties. British Journal of Educational Psychology, 76(4):683-696.

CIMMIYOTTI, CB. 2013. Impact of reading ability on academic performance at the primary level (Master's theses and Capstone projects. Paper 127). Dominican University, River Forest, IL.

CLAYMAN, SE \& VT GILL. 2004. Conversation Analysis. In: Bryman, M. \& Hardy, A. (eds.). Handbook of Data Analysis, London: Sage. 589-606.

Department of Basic Education (2010). [On line]. Home Language. Curriculum and Assessment Policy Statement (CAPS). Pretoria: Department of Basic Education. Available from http://www.thutong.doe.gov.za. [Accessed 13/3/2017].

DEWEY, J. 1963. Experience and education. New York: Collier Books. (Original work published 1938).

DU PREEZ, WC. 2015. Dialogic learning in a second language poetry class: how interaction patterns relate to the learning and understanding of metaphors (Doctoral dissertation, University of Johannesburg).

EDWARDS, D. 1997. But What Do Children Really Think? Discourse Analysis and Conceptual Content in Children's Talk. Cognition and Instruction, 11:207-225.

EDWARDS, JA. 2001. 'The transcription of discourse', in D. Schiffrin, D. Tannen and H.E. Hamilton (eds) The Handbook of Discourse Analysis, pp. 321-48. Malden, MA/ Oxford, UK/Carlton, Vic: Blackwell.

GARFINKEL, H. 1967. [On line]. Studies in Ethnomethodology. Available from https://monoskop.org/images/0/0c/Garfinkel_Harold_Studies_in_Ethnomethodology.pdf, [Accessed 10/10/2016].

GILLIES, RM. 2016. Cooperative learning: Review of research and practice. Australian journal of teacher education, 41(3):39-54.

GRIMM, KJ. 2008. Longitudinal associations between reading and mathematics achievement. Developmental neuropsychology, 33(3):410-426.

HOWIE, SJ, C COMBRINCK, M TSHELE, K ROUX, N MCLEOD PALANE, \& G MOKOENA. 2018. PIRLS 2016 Progress in International Reading Literacy Study 2016 Grade 5 benchmark participation: South African children's reading literacy achievement. Centre for Evaluation and Assessment (CEA).

HURTS, B. R WALLACE \& SB NIXON. 2013. The Impact of Social Interaction on Student Learning. Reading Horizons, 52(4):375-398.

JEFFERSON, G. 1984. Transcription Notation. In: J. Atkinson \& J. Heritage (eds), Structures of Social Interaction. New York: Cambridge University Press.

JOHNSON, K. (1995). Understanding Communication in Second Language Classrooms. Cambridge: Cambridge University Press.

KIEMER, K. A GRÖSCHNER, AK PEHMER \& T SEIDEL. 2015. Effects of a classroom discourse intervention on teachers' practice and students' motivation to learn mathematics and science. Learning and Instruction, 35:94-103.

KOOLE, T. ED ELBERS. 2014.Responsiveness in teacher explanations: A conversation analytical perspective on scaffolding. Linguistics and Education, 26: 57-69.

KOSCHMANN, T. 1999. Towards a Dialogic Theory of Learning: Bakhtin's Contribution to Understanding Learning in Settings of Collaboration. Computer Support for Collaborative Learning. 308-312.

KOZULIN, A. 2003. Psychological tools and mediated learning. Vygotsky's educational theory in cultural context, 15-38.

KUCAN, L \& I BECK. 1997. Thinking aloud and reading comprehension research: Inquiry, Instruction and Social interaction. Review of educational research, 67(3):271-299.

LINDEMAN, EC. 1926. The meaning of adult education (Redistributed edition 1989 ed.). New York: New Republic.

MAGANO, D, P. MOSTERT \& GJ VAN DER WESTHUIZEN 2010. Learning Conversations. The value of interactive learning. Heinemann, Johannesburg.

MELANDER, H. 2012. Transformations of knowledge within a peer group. Knowing and learning in interaction. Learning, Culture and Social Interaction, 1(3-4):232-248.

Per Linguam 2020 36(2):1-15

http://dx.doi.org/10.5785/36-2-910 
MERCER, N, L DAWES \& JK STAARMAN. 2009. Dialogic teaching in the primary science classroom. Language and education, Learning over time: empirical and theoretical investigations of classroom talk and interaction, 23:353-369.

MERCER, N \& C HOWE. 2012. Explaining the dialogical processes of teaching and learning: The value and potential of socio-cultural theory. Learning, culture and social interaction, 12-21.

MERCER, N \& K LITTLETON. 2007. Dialogue and the development of children's thinking: A sociocultural approach. London: Routledge.

MICHAELS, S \& C O'CONNER. 2012. Talk science primer. Cambridge, MA: TERC.

MONDADA, L. 2011. Understanding as an embodied, situated and sequential achievement in interaction. Journal of Pragmatics, 43(2):542-552.

NYSTRAND, M, LL WU, A GAMORAN, S ZEISER, \& D LONG. 2003. Questions in time: Investigating the unfolding structure of classroom discourse. National Reseach Center on English Learning and Achievement. Albany: NY

OCZKUS, LD. 2003. Reciprocal Teaching at Work: Strategies for Improving Reading Comprehension. International Reading Association: Newmark.

PALINCSAR, AS. 1986. The role of dialogue in providing scaffolded instruction. Educational Psychologist, 21(1-2):73-98.

PALINSCAR, AS \& AL BROWN. 1984. Reciprocal Teaching of Comprehension. Fostering and Comprehension Monitoring Activities. Cognition and Instruction, 2:117-175.

PARIS, SG, DR CROSS \& MY LIPSON. 1984. Informed strategies for learning: A program to improve children's reading awareness and comprehension. Journal of Educational Psychology, 76(6):1239.

PARIS, SG \& P WINOGRAD. 1990. Promoting metacognition and motivation of exceptional children. Remedial and Special Education, 11(6):7-15.

PELLEGRINO, JW. 2020. Sciences of learning and development: Some thoughts from the learning sciences. Applied Developmental Science, 24(1):48-56.

PRESSLEY, M, P EL-DINARY, I GASKINS, T SCHUDER, J BERGMAN, J ALMASI \& $\mathrm{R}$ BROWN. 1992. Beyond Direct Explanation: Transactional Instruction of Reading Comprehension Strategies. The Elementary School Journal, 92(5):513-555.

PRETORIUS, AJ. 2015. Structural Dimensions of Mentoring Conversations. In: Tillema, HH, GJ van der Westhuizen, K Smith. (Eds). Mentoring for learning: Climbing the mountain. Springer, Verlag. 139-154.

RENNINGER, KA \& S HIDI. 2011. Revisiting the conceptualization, measurement, and generation of interest. Educational Psychologist, 46(3):168-184.

RICKETTS, J, R SPERRING \& K NATION. 2014. Educational attainment in poor comprehenders. Frontiers in Psychology, 5:445. https://doi.org/10.3389/fpsyg.2014.00445

RO, E. 2019. How learning occurs in an extensive reading book club: A conversation analytic perspective. Applied Linguistics, 40(1):152-175.

ROSENSHINE, B. \& C MEISTER. 1994. Reciprocal teaching: A review of the research. Review of Educational Research, 64(4):479-530.

RSA DBE (Republic of South Africa. Department of Basic Education). 2014. Annual National Assessment 2014: Report on the ANA of 2013. Pretoria: Department of Basic Education.

SACKS, H. 1992a. Lectures on conversation. 2 vols. Edited by Gail Jefferson with introductions by Emanuel A. Schegloff: Oxford: Basil Blackwell.

SEEDHOUSE, P. 2004. The interactional architecture of the language classroom: A conversation analysis perspective. Oxford: Blackwell.

SIMPSON, A, N MERCER \& Y MAJORS. 2010. Editorial: Douglas Barnes revisited: If learning floats on a sea of talk, what kind of talk? And what kind of learning? English Teaching: Practice and Critique, 9(2):1-6.

SLAVIN, RE. 2015. Cooperative learning in elementary schools. Education 3-13, 43(1):5-14.

STAHL, G. 2002. Contributions to a theoretical framework for CSCL. In G. Stahl (Ed.), Proceedings of CSCL 2002. USA: Boulder. 62-71.

TANNER, Marie. Taking interaction in literacy events seriously: a conversation analysis approach to evolving literacy practices in the classroom. Language and Education, 2017, 31.5: 400-417.

Per Linguam 2020 36(2):1-15

http://dx.doi.org/10.5785/36-2-910 
TEN HAVE, P. 2007. Doing conversation analysis. London: Sage.

VAN DER BERG, S. 2016, June 2. Leerlinge verstaan nie wat hulle lees. Beeld, p. 3.

VAN DER WESTHUIZEN, GJ. 2015. The role of knowledge in mentoring conversations, 119-138.

Tillema, HH, GJ van der Westhuizen \& K. Smith. (Eds.). 2015. Mentoring for learning.

Climbing the mountain. Rotterdam, Sense Publishers.

VAN DER WESTHUIZEN, G, H DUNBAR-KRIGE, C. BACHRACH 2018. 'Go bolela, go a shikinya'-Shaking utterances in learning interactions. South African Journal of Education, 38(1):1-12.

VAN DER WESTHUIZEN, GJ, AJM PRETORIUS \& HH TILLEMA. 2020. Learning trouble in mentoring conversations. Southern African Linguistics and Applied Language Studies, 38(2), $167-181$.

VAN STADEN, S. 2011. Factors that affect South African Reading Literacy Achievement: Evidence from prePIRLS 2011. South African Journal of Education, 34(3):1-9.

VAN STADEN, S \& R BOSKER. 2014. Factors that affect South African reading literacy achievement: evidence from prePIRLS 2011. South African Journal of Education, 34(3):1-9.

VYGOTSKY, LS. 1986. Thought and Language. Cambridge: MIT Press.

WALSHAW, M \& G ANTHONY. 2008. The teacher's role in classroom discourse: a review of recent research into mathematics classrooms. Review of Educational Research, 78(3):516-551.

WILLEMSEN, A, MN GOSEN, M VAN BRAAK, T KOOLE, \& K DE GLOPPER. 2018. Teachers' open invitations in whole-class discussions. Linguistics and Education, 45:40-49.

WOLF, MK, AC CROSSON \& LB RESNICK. 2005. Classroom talk for rigorous reading comprehension instruction. Reading Psychology, 26(1):27-53.

\section{BIOGRAPHICAL NOTES}

Nastassja Maree is an educational specialist and HOD at Laerskool Rooihuiskraal. She obtained her $\mathrm{PhD}$ with specialisation in learner support, school guidance and counselling from the University of Pretoria in 2020. Her research interests include innovative pedagogical practices and the establishment of intervention measures to facilitate life-long learning and development. Email address: nastassjamaree@1srhk.co.za

Gert van der Westhuizen is professor of Education Emeritus, University of Johannesburg. His research focus is on interactional learning in school and community environments. Current research projects include conversation analysis studies of remote and online learning in educational change and growth points. Email address: gertvdw@uj.ac.za 


\section{Addendum A:}

\section{Transcription notations}

Jeffersonian Transcription Notation includes the following symbols:

\begin{tabular}{|c|c|c|}
\hline Symbol & Name & Use \\
\hline [ text ] & Brackets & $\begin{array}{l}\text { Indicates the start and end points of overlapping } \\
\text { speech. }\end{array}$ \\
\hline$=$ & Equal Sign & $\begin{array}{l}\text { Indicates the break and subsequent continuation of a } \\
\text { single interrupted utterance. }\end{array}$ \\
\hline $\begin{array}{ll}(\# & \text { of } \\
\text { seconds) }\end{array}$ & Timed Pause & $\begin{array}{l}\text { A number in parentheses indicates the time, in } \\
\text { seconds, of a pause in speech. }\end{array}$ \\
\hline (.) & Micropause & A brief pause, usually less than 0.2 seconds. \\
\hline . or $\downarrow$ & $\begin{array}{l}\text { Period or Down } \\
\text { Arrow }\end{array}$ & Indicates falling pitch. \\
\hline ? or $\uparrow$ & $\begin{array}{l}\text { Question Mark } \\
\text { or Up Arrow }\end{array}$ & Indicates rising pitch. \\
\hline , & Comma & Indicates a temporary rise or fall in intonation. \\
\hline- & Hyphen & Indicates an abrupt halt or interruption in utterance. \\
\hline$>$ text $<$ & $\begin{array}{l}\text { Greater than / } \\
\text { Less than } \\
\text { symbols }\end{array}$ & $\begin{array}{l}\text { Indicates that the enclosed speech was delivered more } \\
\text { rapidly than usual for the speaker. }\end{array}$ \\
\hline$\langle$ text $>$ & $\begin{array}{l}\text { Less than / } \\
\text { Greater than } \\
\text { symbols }\end{array}$ & $\begin{array}{l}\text { Indicates that the enclosed speech was delivered more } \\
\text { slowly than usual for the speaker. }\end{array}$ \\
\hline$\circ$ & Degree symbol & Indicates whisper or reduced volume speech. \\
\hline ALL CAPS & Capitalized text & Indicates shouted or increased volume speech. \\
\hline underline & Underlined text & $\begin{array}{l}\text { Indicates the speaker is emphasizing or stressing the } \\
\text { speech. }\end{array}$ \\
\hline$\because::$ & Colon(s) & Indicates prolongation of an utterance. \\
\hline (hhh) & & Audible exhalation \\
\hline ? or $(. h h h)$ & High Dot & Audible inhalation \\
\hline ( text) & Parentheses & Speech which is unclear or in doubt in the transcript. \\
\hline$(($ italic text $))$ & $\begin{array}{l}\text { Double } \\
\text { Parentheses }\end{array}$ & Annotation of non-verbal activity. \\
\hline
\end{tabular}

Jeffersonian Transcription Notations. "Transcription Notation," in J. Atkinson and J. Heritage (eds), Structures of Social Interaction, New York: Cambridge University Press, 1984. 